Dept. of Internal and Preventive Medicine,

College of Veterinary Medicine,

University of Mosul, Mosul, Iraq.

\title{
EXPERIMENTAL STUDY FOR EVALUATION OF ANTIMICROBIAL ACTIVITY OF THE AQUEOUS GARLIC EXTRACT IN TREATMENT OF ARTHRITIS IN RABBITS
}

(With 3 Tables and One Figure)

By

MOHAMMAD A. AL-TALIBI

(Received at 28/8/2011)

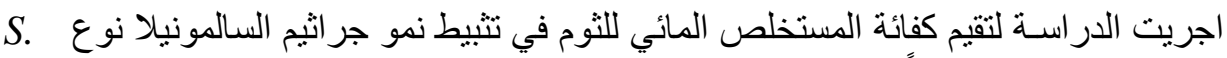

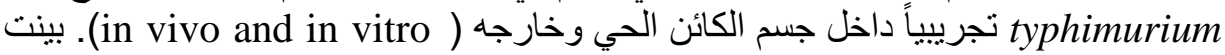

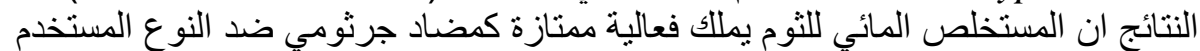

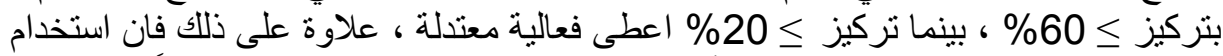

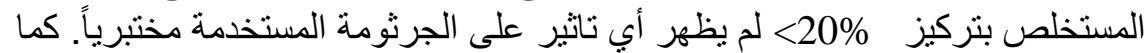

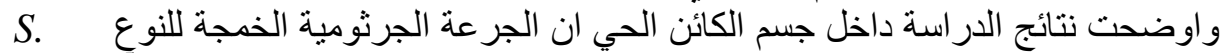
Ityphimurium

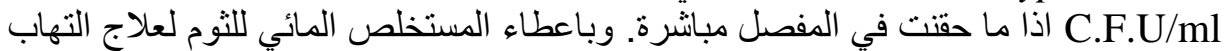

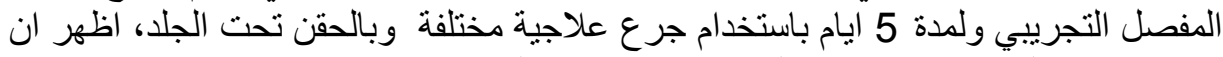
كمان

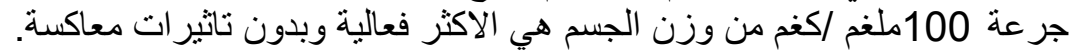

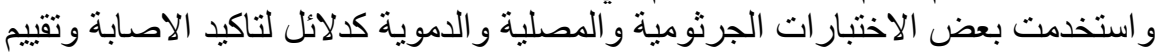

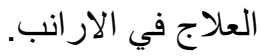

\section{SUMMARY}

The study was conducted to evaluate the ability of Aqueous Garlic Extract (AGE) for inhibition the growth of Salmonella typhimurium as a probable cause of arthritis in rabbits in vitro and in vivo study. Results revealed that AGE (contain $201.2 \mu \mathrm{g} / \mathrm{ml}$ allicin) have excellent antibacterial activity against this strain at $\geq 60 \%$ concentration, while the concentration $\geq 20 \%$ showed moderate activity, $\mathrm{M}$ oreover concentration of $<20 \%$ show no effect in vitro. The in vivo study was explained the infectious dose of Salmonella typhimurium that induce arthritis in 
experimental animals was $\geq 1 \times 10^{5} \quad$ C.F.U/ml when injected intrarticularly. Garlic extract was administrated to treat experimental induced arthritis for 5 days by using different doses subcutaneously. It have been shown that a dose rate of $100 \mathrm{mg} / \mathrm{kg}$ B.W S.C were more effective and have no adverse effects. Some bacteriology, serology and hematological tests were used as indicators to confirm infection and evaluation of treatment in rabbits.

\section{Key words: Garlic Extract, treatment, Arthritis, Salmonella typhimurium.Rabbit.}

\section{INTRODUCTION}

The increased numbers of bacteria that are developing resistance to classical antibiotics (Levy, 1997; Cole et al., 2002) drive much of the current interest on plant antimicrobial molecules in hope that they may provide useful leads into anti-infective drug candidates. Several antimicrobial agents were isolated from plant such as garlic (Allium sativum) Komgeum et al. (2005), that has traditional dietary and medicinal applications as an anti-infective agent Ross et al. (2001). Garlic is a common food spice widely distributed and used in all parts of the world as a spice and herbal medicine for the prevention and treatment of a variety of diseases, ranging from infections to heart diseases Rivlin (2001). Garlic is a strong antibacterial agent and acts as an inhibitor on both Gram-positive and Gram-negative bacteria including such species as Escherichia, Salmonella, Streptococcus, Staphylococcus, Klebsiella, Proteus and Helicobacter pylori (Ankri and Mirelman, 1999). The bulbs contain an odorless sulfur containing amino acid called alliin (s-allyl-1- cysteine sulfoxide), which has no pharmacologic activity (Castleman, 1991). When the bulb is grinded, the enzyme allinase is released which results in the conversion of alliin to 2 - propenesulforic acid, which dimerizes to form allicin, Allicin gives the pungent characteristic odor to crushed garlic and is believed to be responsible for some of the pharmacologic activity of the plant (McCaleb, 1993). Allicin is known to have a very broad spectrum antibacterial effect against wide range of microorganism.

It is common to find Klebsiella spp in patients with rheumatoid arthritis and ankylosing spondylitis as well as other inflammatory 
conditions (Reuter, 1996). The anti-microbial effects of garlic is due to the chemical reaction of the allicin with the thiol groups of several enzymes such as ARN Polymerase in the microorganism, and by delaying and inhibiting DNA, RNA and protein synthesis, However the mechanism of action was not well known (Rabinkov et al.,1998; Ankri and Mirelman, 1999). Allicin and other thiosulfinates are somewhat unstable, but dilution and dissolving in water greatly improve their stability, since removal of alliin from garlic, or inactivation of allinase by microwave cooking, eliminates these effects, while adding allicin back into garlic powders so treated restores garlic's antibacterial activity (Lawson, 1998). Allicin at high concentrations has been reported to be a potentially toxic substance (Amagase et al., 2001). The investigations of acute toxicity of allicin have shown that, with rats, the LD50 value amounts $60 \mathrm{mg} / \mathrm{kg}$ (when administered intravenously), and $120 \mathrm{mg} / \mathrm{kg}$ (for a subcutaneous administration), The application of high doses of allicin can cause a number of disorders in the organism, sometimes hepato-toxicity may occur, allergic reactions on the skin and mucous membrane, with profuse hemorrhages, bleeding is further increased (Koch, 1992).

The aim of this study was to investigate the antimicrobial effect of AGE in treatment of arthritis in rabbits that was induced experimentally by Salmonella typhimurium, which was chosen as gram negative model organism as it's one of major animal and human pathogens may causing polyarthritis and whose resist to wide range of antimicrobial preparations (Reed, 1993; Martin et al., 1995; Radostits et al., 2007).

Abbreviations: AGE; aqueous garlic extract, C.F.U; colony forming unit, B.W; body weight, LD50; lethal dose of $50 \%$ of animals, rpm; round per minute, ID50; infectious dose of $50 \%$ of animals, ESR; erythrocyte sedimentation rate, RF; rheumatoid factor.

\section{MATERIALS and METHODS}

\section{1 - Preparation of Aqueous Garlic Extract}

Fresh garlic was washed and prepared for the crude juice extraction. One hundred grams of cleaned garlic bulbs with $125 \mathrm{ml}$ of distilled water were crushed in a juicer. The mixture was then filtrated and further centrifuged at $10000 \mathrm{rpm}$ for $20 \mathrm{~min}$. The supernatant was filtered through a $0.45 \mu \mathrm{m}$ millipore filter to remove microorganisms 
(sterilization). By subtracting the weight of the insoluble material from the original garlic cloves, the final concentration of the garlic extract in solution was determined to be $249 \mathrm{mg} / \mathrm{mL}(201.2 \mu \mathrm{g} / \mathrm{ml}$ of allicin). Aliquots were stored at $-20^{\circ} \mathrm{C}$ until required (Chen et al., 2009).

\section{2- Bacterial and growth condition}

Salmonella typhimurium organisms included in this study were obtained from Central Health Laboratory (CHL) in Baghdad-Iraq. The storage of bacterial samples was at $4{ }^{\circ} \mathrm{C}$ until use in sterile nutrient agar. A preculture was prepared by transferred from this slant to sterile enrichment broth (peptone water broth) and cultivate at $37^{\circ} \mathrm{C}$ for $18 \mathrm{~h}$.

\section{3 - Antibacterial sensitivity testing using filter paper method}

Filter paper discs of $7 \mathrm{~mm}$ diameter were prepared and sterilised. Using an ethanol dipped and flamed forceps, these discs were aseptically placed over nutrient agar plates cultured with bacterial strain. One hundred micro litres of the AGE at different concentration $(1 \%, 10 \%$, $20 \%, 40 \%, 60 \%, 80 \%$ and $100 \%$ ) were aseptically transferred to these discs. The plates were incubated at $37^{\circ} \mathrm{C}$ for 24 hours. The diameter of inhibition zones were measured in $\mathrm{mm}$ and the results were recorded. Inhibition zones with diameter less than $12 \mathrm{~mm}$ were considered as having no antibacterial activity. Diameters between 12 and $16 \mathrm{~mm}$ were considered moderately active, and these with $>16 \mathrm{~mm}$ were considered highly active (Srinivasan et al., 2001).

\section{4 - Experimental animals}

Twenty local bread female rabbits at one year of age. Its relatively equal in size weighting 1.350 to $1.700 \mathrm{~kg}$, and they were maintained on standard rabbits food and water without additional of any antibiotics. The rabbits were divided into five groups, four animals for each (A,B,C,D and E). Each group was stayed under room temperature $\left(25^{\circ} \mathrm{C}\right)$ in special cages for one week before examination at laboratory animal house at Collage of Vet. Med., University of Mosul. All animals were examined clinically and by some laboratory tests to excluded any diseased one.

\section{5 - Determination of ID50 value of Salmonella typhymurium}


The method used for determining ID50 value was modified from report of (Ishibashi and Arai, 1996; Tortora et al., 2001). The tested rabbits were divided into 5 groups $(\mathrm{A}, \mathrm{B}, \mathrm{C}, \mathrm{D}, \& \mathrm{E})$ four animals for each, The last group $\mathrm{E}$ use act as control negative, where it was injected with normal saline only (un infected). The other groups were injected successfully intra articularly after 10 fold serial dilution. The concentration was determined by plate count in triplicate. A total of $0.1 \mathrm{ml}$ of bacterial suspension from each dilution was injected under sterile conditions at hock joint to induce arthritis. The clinical signs of each one were observed, Identified the infection was done by some laboratory tests and measuring of joint diameter by engineering caliper.

\section{6 - Diagnostic tests}

Laboratory tests were applied to all animals under study before and after experimental infection and after treatment application, that's used as indicators of the infection and evaluation of treatment. Such tests includ bacterial swab culture of stool and joint fluid on salmonellashigella and nutrient agar, ESR mm/hr (Manning et al., 1994; Pisetsky, 2007), Rheumatoid factor by latex test (Coles, 1986; Hanglow et al., 1986), Leukocyte and Lymphocyte count. In addition total RBC count and hemoglobin concentration $\mathrm{g} / \mathrm{dl}$ was applied. The blood samples were collected from marginal ear vein of rabbits by using vacutaner tubes.

\section{7 - Treatment procedure}

Three animals for each infected groups. The extract was injected at different concentration $(50,70,100,110 \mathrm{mg} / \mathrm{kg}$ of body weight) after diluted 1:10 with normal saline $0.9 \%$ subcutaneously/day for 5 days for each group except the last has injected with normal saline $0.9 \%$ only that considered as control positive group.

\section{8 - Statistical analyses were done by using student's t-test by SPSS (12.0) for windows computing program.}




\section{RESULTS}

\section{In vitro study:}

The aqueous garlic extract showed high antibacterial activity against Salmonella typhimurium at $100 \%, 80 \%$ and $60 \%$ concentration. However $40 \%$ and $20 \%$ concentration of extract also showed moderate antibacterial activity against this strain, while concentration $<20$ showed no effect (Figer-1). Results revealed that infectious dose of Salmonella typhimurium that causing arthritis in rabbits is $\geq 1 \times 10^{5}$ C.F.U/ml when injected directly intra articularly in rabbits, moreover diseased animals exhibit loss of appetite, lameness, increase body temperature with heart and respiratory rate, swelling of affected joint, RF was positive with significant elevation $(\mathrm{p}<0.05)$ of ESR value and increasing of total leukocytic and lymphocyte count in blood (Table-2).

By using a different doses $(50,70,100 \& 110 \mathrm{mg} / \mathrm{kg} \mathrm{B.W.)} \mathrm{of}$ AGE in treatment of experimental arthritis in rabbits, results indicated that $100 \mathrm{mg} / \mathrm{kg} \mathrm{B.W}$. are more effective and more safety dose when compared with other doses in treatment procedure. The bacterial culture of joint fluid gave a negative results in group $\mathrm{C}$ and $\mathrm{D}$, while group $\mathrm{A}$ and $\mathrm{B}$ remain positive for salmonella growth after treatment. There were a significant decrease $(\mathrm{p}<0.05)$ of body temperature at day 4 after treatment of animals in group $\mathrm{C} \& \mathrm{D}$. The joint diameter was decreased at day 4 and 14 after treatment by $100 \& 110 \mathrm{mg} / \mathrm{kg}$ B.W while the control group $E$ recorded a significant elevation $(p<0.05)$ at day14. There are a significant decrease $(\mathrm{p}<0.05)$ in ESR value in group $\mathrm{C}$ at day 14 after treatment. The RF returned to normal partially in $\mathrm{C}$ and $\mathrm{D}$ group after treatment. There is decrease of total leukocytic and lymphocyte count at day14 after treatment of animals in group $\mathrm{C}$ and $\mathrm{D}$. The clinical signs of animals in group $\mathrm{C}$ and $\mathrm{D}$ was normal after treatment, in addition of significant decrease $(p<0.05)$ of total RBC count and hemoglobin concentration in group D only at day 14 with clinical appearance of coffee like urine at day 5 during time of treatment. Rabbits whose treated with low concentration of AGE $(50,70 \mathrm{mg} / \mathrm{kg}$ B.W) have no respond to treatment by depending on clinical and diagnostic test (Table-3). 
Fig. 1: Growth curve of Salmonella typhimurium in solid media at $37^{\circ} \mathrm{C}$ treated with different concentration of AGE (\%) by filter paper method.

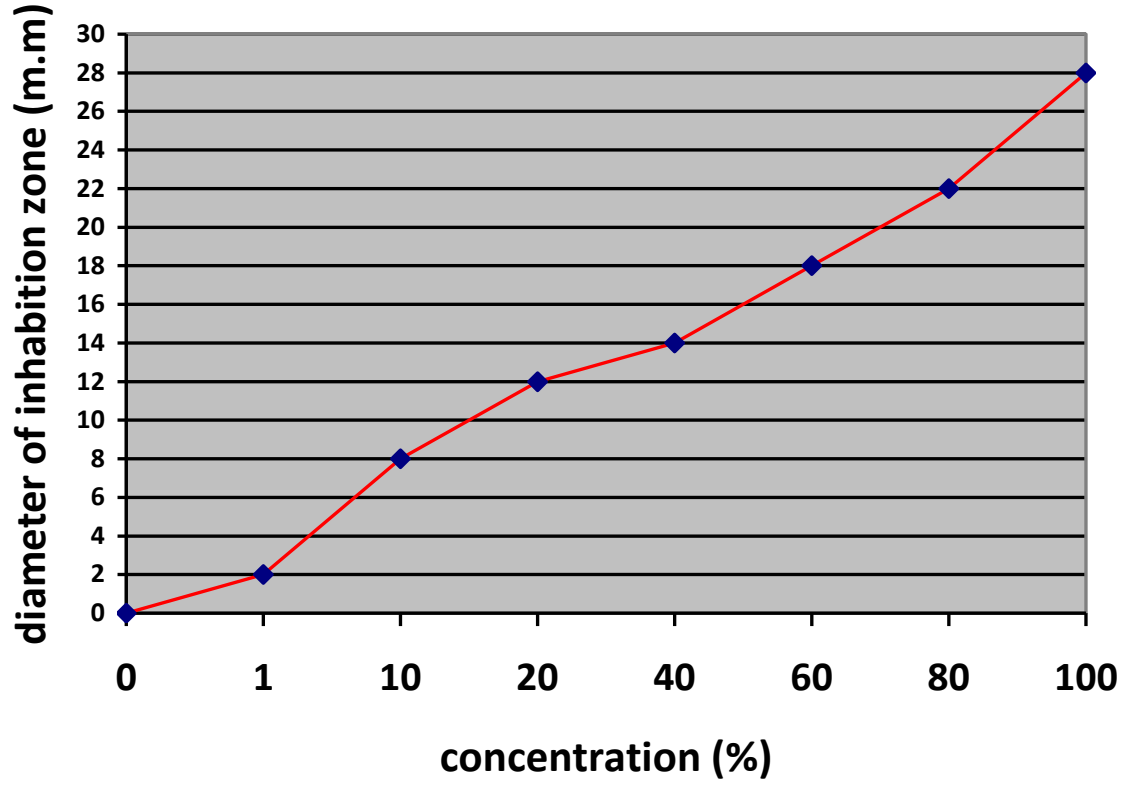

Table 1: Some parameters that are used as indicators about infection free of experimental rabbits.

\begin{tabular}{|c|c|c|c|c|c|}
\hline \multirow[b]{2}{*}{ Parameters } & \multicolumn{5}{|c|}{ Animals groups } \\
\hline & A & B & $\mathrm{C}$ & $\mathrm{D}$ & $\mathrm{E}$ \\
\hline Stool culture & $\ldots$ & $\ldots$ & $\ldots$ & $\ldots$ & $\ldots$ \\
\hline Joint fluid culture & $\ldots$ & $\ldots$ & $\ldots$ & - - - - & $\ldots$ \\
\hline Heart rate/min & $121.0 \pm 1.0$ & $126 \pm 2.5$ & $119 \pm 1.0$ & $120 \pm 0.0$ & $127.5 \pm 2.5$ \\
\hline Respiratory rate & $110.5 \pm 0.5$ & $114 \pm 1.0$ & $111 \pm 1.0$ & $111.5 \pm 1.5$ & $118.5 \pm 3.5$ \\
\hline Body temp. ${ }^{\circ} \mathrm{C}$ & $39.0 \pm 0.0$ & $39.0 \pm 0.0$ & $39.0 \pm 0.0$ & $39.0 \pm 0.0$ & $39.0 \pm 0.0$ \\
\hline Joint diameter $/ \mathrm{cm}$ & $1.3 \pm 0.0$ & $1.2 \pm 0.10$ & $1.15 \pm 0.05$ & $1.25 \pm 0.05$ & $1.30 \pm 0.0$ \\
\hline ESR m.m/hr. & $1.0 \pm 0.0$ & $1.5 \pm 0.5$ & $2.0 \pm 0.0$ & $1.5 \pm 0.5$ & $2.0 \pm 0.0$ \\
\hline RF & $\ldots-$ & $-\ldots$ &.-- &.-- & --- \\
\hline $\mathrm{T} \mathrm{WBC} \times 10^{3} / \mu \mathrm{l}$ & $8.50 \pm 0.2$ & $8.05 \pm 0.05$ & $8.25 \pm 0.05$ & $8.6 \pm 0.1$ & $8.0 \pm 0.1$ \\
\hline Lymphocyte \% & $66.35 \pm 2.75$ & $62.7 \pm 0.35$ & $57.45 \pm 2.75$ & $58.05 \pm 1.45$ & $60.0 \pm 0.4$ \\
\hline $\mathrm{T} \mathrm{RBC} \times 10^{6} / \mu \mathrm{l}$ & $5.81 \pm 0.06$ & $5.53 \pm 0.27$ & $6.09 \pm 0.19$ & $6.0 \pm 0.01$ & $6.15 \pm 0.17$ \\
\hline Hemoglobin g/dl & $11.65 \pm 0.15$ & $12.0 \pm 0.5$ & $11.85 \pm 0.15$ & $11.95 \pm 0.05$ & $12.15 \pm 0.35$ \\
\hline
\end{tabular}

Each value refer to the mean \pm standard error of four animals for each group.

Rheumatoid factor values $<4 \mathrm{I} . \mathrm{U} / \mathrm{ml}$ was consider negative result.

(-) this sign is referring to negative test result. And (- - -) indicate four animal in group. 
Table 2: Some parameters that used as indicators about arthritis by Salmonella typhimurium at different concentration in experimental rabbits. 
Table 3: Some parameters that used as indicators for evaluation of antibacterial activity of AGE in treatment of arthritis in experimental animals. 


\section{DISCUSSION}

A differential effect of the garlic extract on Salmonella typhimurium was also reflected in the cell growth curve performed in this study. Results agreed with observations of previous researchers (Elnima et al., 1983; Kumar et al., 1998; Arora and Kaur, 1999; De et al., 1999). However, garlic extract was unable to inhibit growth under $20 \%$ concentration. The antibacterial activity of the garlic is reported to be as a results the action of allicin (Avato et al., 2000). So, the disability of the extract to inhibit the growth rate suggested that this strain may be able to metabolized the allicin to non inhibitory compound when used at low concentration (Belguith et al., 2010). The inoculation of Salmonella typhimurium at $1 \times 10^{5}$ C.F.U/ml intra articularly to induce arthritis in rabbits caused elevation of body temperature, heart and respiratory rate as a result of antigen stimulation. The responsible evidence that most fever are mediated through the action of endogenous or leukocyte pyrogen production, interleukin-1. This may stimulated the mediator between pyrogen, prostaglandin and hypothalamus. So the effect of bacteria is exerted on the thermoregulatory center in hypothalamus that the thermostatic level of body is rise, the elevation of body temperature was accompanied by increase heart and respiratory rate (Radostits et al., 2007). The present investigation proved that inoculation of bacterial strain at $1 \times 10^{4} \mathrm{CFU} / \mathrm{ml}, 1 \times 10^{3} \mathrm{CFU} / \mathrm{ml}, 1 \times 10^{2} \mathrm{CFU} / \mathrm{ml}$ intra articularly don't induce arthritis in rabbits. This results disagreed with a results of previous study (Volkman and Collins, 1975). The reason may be related with bacterial strain difference between two studies. Bacterial dosage and it's virulence can limits the ability to produce disease (Quinn et al., 2003), especially the researcher was used Salmonella enteritids at $1 \times 10^{3}$. The body temperature, heart and respiratory rate at day14 after infection in group A were decreased and partially return to normal, suggesting that effect of antigen was removed systemically duo to localization in affected joint, so, the heart and respiratory rate decreased as accompanist with decrease body temperature. Joint swelling was appeared in experimental rabbits when injected with $1 \times 10^{5} \mathrm{CFU} / \mathrm{ml}$ at day 7 as a result of sever arthritis and infiltration of inflammatory cells and fluids with in the joint (Hanglow et al., 1986). This agreed with a results that obtained by Volkman and Collins (1975). The bacterial strain was detected viable in affected joint all along the duration of experiment but fewer colony were recovered from affected joint at end of procedure, the fact is that as the joint seems to be natural habitat for microorganism it is reasonable to assume the organisms are at least partially protected from 
host defense mechanism and are able to survive for several days after injection (Washburn et al., 1980). The positive results of RF after bacterial inoculation in joint, that's beyond to the antigen stimulus, initiated the immune response and inflammation in rheumatoid arthritis. Synovial lymphocyte produce IgG that is recognized as foreign and stimulate the immune response with in the joint, IgM and IgG antiimmunoglobulin are produced and known as rheumatoid factor (Coles, 1986). Some individual with rheumatoid arthritis may not have detectable RF (Tizard, 2000). This explained the negative result with RF in one animal in group A. The elevation of ESR level in blood of affected rabbits at day 14 may be due to the speed of erythrocyte fall in the blood. This increased indicator of inflammatory disease and tissue degeneration, and increasing of this speed probably results from changes that's occur in the physiochemical properties of the erythrocyte surface and plasma proteins causing aggregation of red cells (Schalm et al., 2000). The increasing of a total leukocytic count and lymphocyte more than physiological level may occur due to localization of the infection with constant antigen stimulation of immune system causing increase production of total leukocyte (Coles, 1986). The severity of infectious arthritis was manifested by leukocytosis (Radostits et al., 2007).

Arthritis should be treated as an emergency case to avoid irreversible changes in joint. The bacterial culture of joint fluid revealed that's negative in group $\mathrm{C}$ and $\mathrm{D}$ after treatment, while group $\mathrm{A}$ and $\mathrm{B}$ were remain positive although treatment application. This explained the effective dose of the extract that was given subcutaneously is more than $100 \mathrm{mg} / \mathrm{kg} \mathrm{B}$.W. The decreasing of body temperature in animals in group $\mathrm{C}$ and $\mathrm{D}$ at day 4 after starting treatment may reflect the inhibition of the causative agent as a result of effect of extract activity, especially the removal of the pyrogen effect from the body causing cessation of pyrogen-prostaglandin-hypothalamus complex, so, the body temperature returned to normal (Radostits et al., 2007). Decreased joint diameter was appeared at day 4 and 14 after treatment in group C and D may be explained the removal of causative agent from joint causing inhibition of inflammatory reaction, so, the infiltration of inflammatory cells and accumulation of edematous fluid in side the joint was decreased (Hanglow et al., 1986). The decreasing of total leukocytic and lymphocyte count after treatment in group $\mathrm{C}$ and $\mathrm{D}$ may be as a result of decreased stimulation of immune system by bacterial agent due to effect of treatment (Coles, 1986). When the inflammatory complications are removed, the physiochemical properties of blood and plasma returned to 
normal, However, the different values especially ESR go back to normal range in more cases (Schalm et al., 2000). The decreasing of total RBC and hemoglobin concentration after treatment and the appearance of coffee like urine in the animals in group D may be due to the application of high dose of allicin that could cause a number of disorders in the organism, such as destructions of RBC in the circulation (Koch, 1992). However the using $100 \mathrm{mg} / \mathrm{kg} \mathrm{B}$.W SC. for five days of AGE gave good results in treating arthritis in experimental rabbits, So, the present study recommended that application of this experiment on the large animals to observes the effect of extract as antimicrobial agent against of salmonellosis by different routes of administration.

\section{REFERENCES}

Amagase, H.; Petesch, B.L.; Matsuura, H.; Kasuga, S.and Itakura, Y. (2001): Intake of garlic and its bioactive components J. Nutr. 131: $955 \mathrm{~s}-62 \mathrm{~s}$.

Ankri, S. and Mirelman, D. (1999): Antimicrobial properties of allicin from garlic. Microbes and Infection 1: 125-129.

Arora, D.S. and Kaur, J. (1999): Antimicrobial activity of spices. Int. J. Antimicrob. Agents, 12(3): 257-62 .

Avato, P.; Tursil, E.; Vitali, C.; Miccolis, V. and Candido, V. (2000): Allylsulfide constituents of garlic volatile oil as antimicrobial agents. Phytomedicine, 7(3): 239-243.

Belguith, H.; Kthiri, F.; Chati, A.; Abu Sofah, A.; Ben Hamida, J.; Ladoulsi, A. (2010): Inhibitory effect of aqueous garlic extract (Allium sativum) on some isolated Salmonella serovars. African Journal of Microbiology Research, 4(5): 338-328.

Castleman, M. (1991): The Healing Herbs.Emmanus, PA: Rodale Press 3: $95-96$

Chen Y.; Chiu, H. and Wang, A.Y. (2009): Effects of garlic extract on acid production and growth of Streptococcus mutans. Journal of Food and Drug Analysis. 17, 1: 59-63.

Coles, E.H. (1986): Veterinary Clinical Pathology. $4^{\text {th }}$ ed., WB Saunders Co., Philadelphia; .P.20-21-65-67-314-315.

Cole, A.M.; Hong, T.; Nguyen, T.; Zhae, C.; Bristol, G,; Zack, J.A.; Waring, A.J. and Yang, O.O. (2002): Retrocyclin: A primate peptide that protects cells from infection by T- and M-tropic stains of HIV-1. Proc. Natl. Acad.Sci. USA 99: 1813-1818.

De, M.; Krishna De, A. and Banerjee, A.B. (1999): Antimicrobial screening of some Indian spices. Phytother. Res., 13(7): 616-618. 
Elnima, E.I.; Ahmed, S.A.; Mekkawi, A.G. and Mossa, J.S. (1983): The antimicrobial activity of garlic and onion extracts. Pharmazie, 38(11): 747-748.

Hanglow, A.C.; Welsh, C.J.R.; Conn, P.; Pitts, J.M.; Rampling, A. and Coombs, R.R.A. (1986): Experimental induction of rheumatoid factor and joint lesions in rabbits after intravenous injections of killed bacteria. Annals of the Rheumatic Diseases. 45: 50-59.

Ishibashi, Y. and Arai, T. (1996): A possible mechanism for hostspecific pathogenesis of Salmonella serovars. Microb. Pathog. 21: 435-446.

Kumar, M. and Berawal, J.S. (1998): Sensitivity of food pathogens to garlic (Allium sativum) J. Appl. Bacteriol., 84(2): 213-215.

Komgeum, J.; Meli, A.L.; Manfou, R.N.; Lontsi, D.; Ngounou, F.N.; Kuete, V.; Kamdem, H.W.; Tane, P.; Ngadjui, B.T.; Sondengam, B.L. and Connolly, J.D. (2005): Xanthones from Garcinia smeathmannii (Oliver) and their antimicrobial activity. Phytochem. 66: 1713-1717.

Koch, H.P. (1992): Analytische Bewertung von Knoblaucholmazeraten, Dtsch. Apoth. Ztg. 27: 1419-1426.

Lawson, L.D. (1998): Garlic: A review of its medicinal effects and indicated active compounds In: Lawson, L.D., Bauer, R., eds. Phytomedicines of Europe: Chemistry and Biological Activity. Amer. Chem. Soc. Symposium Series 691. Washington D.C.: Amer. Chem. Soc; 176-209.

Levy, S.W. (1997): Antibiotic resistance: origins, evolution, selection and spread. Chichester, Ciba Foundation Symposium pp. 1-14.

Manning, P.J.; Ringler, D.H. and Newcomer, C.E. (1994): The Biology of the Laboratory Rabbit, $2^{\text {nd }}$ ed., Academic Press Limited, 24-28 Oval Rd, London NW1 7DX. P. 111-113.

Martin, E.H.; Hubbert, W.T. and Hagsted, H.V. (1995): Zoonoses. $1^{\text {st }}$ ed. Iowa State University Press, Ames. p. 280-282.

McCaleb, R. (1993): Antioxidant, antitumor, and cardiovascular actions of garlic. Herbal Gram. 29: 18.

Pisetsky, DS. (2007): Laboratory testing in the rheumatic diseases. In: Goldman L and Ausiello D eds. Cecil Medicine. $23^{\text {rd }}$ ed. Philadelphia, Pa: Saunders Elsevier, chap 278.

Quinn, P.J.; Markey, B.K.; Carter, M.E.; Donnelly, W.J. and Leonard, F.C. (2003): Veterinary Microbiology and Microbial Diseases, Blakwell Science Ltd.U.K, P. 36 
Rabinkov, A.; Miron, T.; Konsrantinovski, L.; Wilchek, M.; Mirelman, D. and Weiner, L. (1998): The mode of action of allicin: trapping of radicais and interaction with thiol containing proteins. Biochim. Biophys. Acts.1379: 233-244.

Radostits, O.M.; Gay, C.C.; Hinchcliff, K.W. and Constable, P.D. (2007): Veterinary Medicine. $10^{\text {th }}$ ed., W.B. Saunders Company Ltd. London, New York. p. 46-47-470 -809-828.

Reed, G.H. (1993): Foodborne illness (Part 2): Salmonellosis. Dairy, Food, Environ. San. Dairy. Food Environ. San. 13(12): 706.

Reuter, H.D.; Koch, H.P. and Lawson, D.L. (1996): Therapeuticeffects and applications of garlic and its preparations In: Garlic: The Science and Therapeutic Applications of Allium sativum L. and Related Species, $2^{\text {nd }}$ ed. Koch, H.P. and Lawson, D.L. (Eds.). Baltimore, William and Wilkins,. pp. 135-212.

Rivlin, R.S. (2001): Historical perspective on the use of garlic. J. Nutr. 31 (3): 951-954.

Ross, Z.M.; O'Gara, E.A.; Hill, D.J.; Sleightholme, H.V. and Maslin , D.J. (2001): Antimicrobial Properties of Garlic Oil against Human Enteric Bacteria: Evaluation of Methodologies and Comparisons with Garlic OilSulfides and Garlic Powder. Appl. Environ. Microbiol. 67: 475-480.

Schalm, O.W.; Feldman, B.F.; Zinki, J.Z. and Jain, N.C. (2000): Veterinary Haematology, Lea and Febiger, Philadelphia.

Srinivasan, D.; Sangeetha, N.; Suresh, T. and Lakshmanaperumalsamy, P. (2001): Antimicrobial activity of certain Indian medicinal plants used infolkloric medicine. J. Ethnopharmacol., 74: 217-220.

Tizard, IR.. (2000): Veterinary Immunology an Introduction: $6^{\text {th }}$ ed. Elsevier's health science in Philadelphia, 393.

Tortora, G.J.; Funke, B.R. and Case, C.L. (2001): Microbiology an introduction; 7 th ed.; Benjamin Cummings; U.S.A; pp 174-175.

Volkman, A. and Collins, F.M. (1975): Pathogenesis of Salmonellaassociated arthritis in the rat. American Society for Microbiology. 11, 2.

Washburn, L.R.; Cole, B.C.; Ward, J.R. and Gelman, M.I. (1980): Chronic arthritis of rabbits induced by mycoplasmas. I Clinical, microbiologic and histologic features. Arthritis Rheum, 23: 825-836. 


\begin{tabular}{|c|c|c|c|c|c|c|}
\hline \multirow{2}{*}{$\begin{array}{l}\text { Days } \\
\text { after } \\
\text { challenge }\end{array}$} & \multirow[t]{2}{*}{ Parameters } & \multicolumn{5}{|c|}{ Animals groups \& bacterial dosage } \\
\hline & & $\begin{array}{lr}\text { A } & 1 \\
\mathrm{x} 10^{5} & \mathrm{CFU} / \mathrm{ml}\end{array}$ & $\begin{array}{c}\text { B } \\
1 \times 10^{4} \\
\text { CFU/ml }\end{array}$ & $\begin{array}{c}\mathrm{C} \\
1 \times 10^{3} \\
\mathrm{CFU} / \mathrm{ml}\end{array}$ & $\begin{array}{c}\mathrm{D} \\
1 \times 10^{2} \\
\mathrm{CFU} / \mathrm{ml}\end{array}$ & $\begin{array}{l}\text { E control } \\
\text {-ve }\end{array}$ \\
\hline \multirow[t]{12}{*}{0} & $\begin{array}{l}\text { Stool } \\
\text { culture }\end{array}$ & --- & ---- & ---- & --- & --- \\
\hline & $\begin{array}{l}\text { Joint fluid } \\
\text { culture }\end{array}$ & --- & --- & --- & $-\cdots$ & --- \\
\hline & $\begin{array}{l}\text { Heart } \\
\text { rate/min }\end{array}$ & $121.0 \pm 1.0$ & $126 \pm 2.5$ & $119 \pm 1.0$ & $120 \pm 0.0$ & $127.5 \pm 2.5$ \\
\hline & $\begin{array}{l}\text { Respiratory } \\
\text { rate }\end{array}$ & $110.5 \pm 0.5$ & $114 \pm 1.0$ & $111 \pm 1.0$ & $111.5 \pm 1.5$ & $118.5 \pm 3.5$ \\
\hline & $\begin{array}{l}\text { Body temp. } \\
{ }^{\circ} \mathrm{C}\end{array}$ & $39.0 \pm 0.0$ & $39.0 \pm 0.0$ & $39.0 \pm 0.0$ & $39.0 \pm 0.0$ & $39.0 \pm 0.0$ \\
\hline & $\begin{array}{l}\text { Joint } \\
\text { diameter } \\
\text { /cm }\end{array}$ & $1.3 \pm 0.0$ & $1.2 \pm 0.10$ & $1.15 \pm 0.05$ & $1.25 \pm 0.05$ & $1.30 \pm 0.0$ \\
\hline & $\begin{array}{l}\text { ESR } \\
\mathrm{m} . \mathrm{m} / \mathrm{hr} .\end{array}$ & $1.0 \pm 0.0$ & $1.5 \pm 0.5$ & $2.0 \pm 0.0$ & $1.5 \pm 0.5$ & $2.0 \pm 0.0$ \\
\hline & RF & - . - & - - - & - - - & - - - & $-\ldots$ \\
\hline & $\begin{array}{l}\text { T WBC } \\
\times 10^{3} / \mu \mathrm{l}\end{array}$ & $8.50 \pm 0.2$ & $8.05 \pm 0.05$ & $8.25 \pm 0.05$ & $8.6 \pm 0.1$ & $8.0 \pm 0.1$ \\
\hline & $\begin{array}{l}\text { Lymphocyte } \\
\%\end{array}$ & $66.35 \pm 2.75$ & $62.7 \pm 0.35$ & $\begin{array}{l}57.45 \\
\pm 2.75 \\
\end{array}$ & $\begin{array}{l}58.05 \\
\pm 1.45 \\
\end{array}$ & $60.0 \pm 0.4$ \\
\hline & $\begin{array}{l}\text { T } \mathrm{RBC} \\
\mathrm{x} 10^{6} / \mu \mathrm{l}\end{array}$ & $5.81 \pm 0.06$ & $5.53 \pm 0.27$ & $6.09 \pm 0.19$ & $6.0 \pm 0.01$ & $6.15 \pm 0.17$ \\
\hline & $\begin{array}{l}\text { Hemoglobin } \\
\mathrm{g} / \mathrm{dl}\end{array}$ & $11.65 \pm 0.15$ & $12.0 \pm 0.5$ & $\begin{array}{l}11.85 \\
\pm 0.15 \\
\end{array}$ & $\begin{array}{l}11.95 \\
\pm 0.05 \\
\end{array}$ & $\begin{array}{l}12.15 \\
\pm 0.35 \\
\end{array}$ \\
\hline \multirow[t]{4}{*}{1} & $\begin{array}{l}\text { Heart rate } \\
\text { /min }\end{array}$ & $137 \pm 2.0^{*}$ & $128.5 \pm 1.5$ & $119 \pm 1.0$ & $120 \pm 0.0$ & $122.5 \pm 2.5$ \\
\hline & $\begin{array}{l}\text { Respiratory } \\
\text { rate }\end{array}$ & $127 \pm 1.0^{*}$ & $\begin{array}{l}119.5 \\
\pm 0.5^{*} \\
\end{array}$ & $111 \pm 1.0$ & $111.5 \pm 1.5$ & $117.5 \pm 2.5$ \\
\hline & $\begin{array}{l}\text { Body temp. } \\
{ }^{\circ} \mathrm{C}\end{array}$ & $39.5 \pm 0.0$ & $\begin{array}{l}39.15 \\
\pm 0.05 \\
\end{array}$ & $39.0 \pm 0.0$ & $39.0 \pm 0.0$ & $39.0 \pm 0.0$ \\
\hline & $\begin{array}{l}\text { Joint } \\
\text { diameter } \\
\text { /cm } \\
\end{array}$ & $1.3 \pm 0.0$ & $1.2 \pm 0.1$ & $1.15 \pm 0.05$ & $1.25 \pm 0.05$ & $1.3 \pm 0.0$ \\
\hline \multirow[t]{4}{*}{2} & $\begin{array}{l}\text { Heart rate } \\
\text { /min }\end{array}$ & $140 \pm 0.0^{*}$ & $128.5 \pm 1.5$ & $119 \pm 1.0$ & $120 \pm 0.0$ & $123 \pm 3.0$ \\
\hline & $\begin{array}{l}\text { Respiratory } \\
\text { rate }\end{array}$ & $131 \pm 1.0^{*}$ & $120 \pm 0.0^{*}$ & $111 \pm 1.0$ & $111.5 \pm 1.5$ & $118.5 \pm 3.5$ \\
\hline & $\begin{array}{l}\text { Body temp. } \\
{ }^{\circ} \mathrm{C}\end{array}$ & $39.6 \pm 0.1 *$ & $\begin{array}{l}39.15 \\
\pm 0.05 \\
\end{array}$ & $39.0 \pm 0.0$ & $39.0 \pm 0.0$ & $39.0 \pm 0.0$ \\
\hline & $\begin{array}{l}\text { Joint } \\
\text { diameter } \\
\text { /cm } \\
\end{array}$ & $1.3 \pm 0.0$ & $1.2 \pm 0.1$ & $1.15 \pm 0.05$ & $1.25 \pm 0.05$ & $1.3 \pm 0.0$ \\
\hline 3 & Heart rate & $140 \pm 0.0^{*}$ & $126 \pm 1.0$ & $119 \pm 1.0$ & $120 \pm 0.0$ & $122.5 \pm 2.5$ \\
\hline
\end{tabular}


Assiut Vet. Med. J. Vol. 57 No. 131 October 2011

\begin{tabular}{|c|c|c|c|c|c|c|}
\hline & \multicolumn{6}{|l|}{$/ \min$} \\
\hline & $\begin{array}{l}\text { Respiratory } \\
\text { rate }\end{array}$ & $131 \pm 1.0^{*}$ & $120 \pm 0.0^{*}$ & $111 \pm 1.0$ & $111.5 \pm 1.5$ & $113 \pm 2.0$ \\
\hline & $\begin{array}{l}\text { Body temp. } \\
{ }^{\circ} \mathrm{C}\end{array}$ & $39.6 \pm 0.1^{*}$ & $\begin{array}{l}39.05 \\
\pm 0.05\end{array}$ & $39.0 \pm 0.0$ & $39.0 \pm 0.0$ & $39.0 \pm 0.0$ \\
\hline & $\begin{array}{l}\text { Joint } \\
\text { diameter } \\
/ \mathrm{cm}\end{array}$ & $1.3 \pm 0.0$ & $1.2 \pm 0.1$ & $1.15 \pm 0.05$ & $1.25 \pm 0.05$ & $1.3 \pm 0.0$ \\
\hline & $\begin{array}{l}\text { Joint fluid } \\
\text { culture }\end{array}$ & ++++ & ++-- & $-\cdots$ & $-\cdots$ & ---- \\
\hline \multirow[t]{9}{*}{7} & $\begin{array}{l}\text { Heart rate } \\
/ \mathrm{min}\end{array}$ & $121.5 \pm 1.5$ & $126 \pm 1.0$ & $119 \pm 1.0$ & $120 \pm 0.0$ & $122 \pm 2.0$ \\
\hline & $\begin{array}{l}\text { Respiratory } \\
\text { rate }\end{array}$ & $110.5 \pm 0.5$ & $114 \pm 1.0$ & $111 \pm 1.0$ & $111.5 \pm 1.5$ & $118.5 \pm 1.5$ \\
\hline & $\begin{array}{l}\text { Body temp. } \\
{ }^{\circ} \mathrm{C}\end{array}$ & $39.4 \pm 0.05^{*}$ & $39.0 \pm 0.0$ & $39.0 \pm 0.0$ & $39.0 \pm 0.0$ & $39.0 \pm 0.0$ \\
\hline & $\begin{array}{l}\text { Joint } \\
\text { diameter } \\
\text { /cm }\end{array}$ & $1.5 \pm 0.0$ & $1.2 \pm 0.1$ & $1.15 \pm 0.05$ & $1.25 \pm 0.05$ & $1.3 \pm 0.0$ \\
\hline & $\begin{array}{l}\text { Joint fluid } \\
\text { culture }\end{array}$ & ++++ & $\cdots$ & $\cdots$ & $-\cdots$ & $\ldots$ \\
\hline & $\begin{array}{l}\text { T WBC } \\
\times 10^{3} / \mu \mathrm{l}\end{array}$ & $12.45 \pm 0.05 *$ & $8.05 \pm 0.05$ & $8.25 \pm 0.05$ & $8.60 \pm 0.1$ & $8.0 \pm 0.1$ \\
\hline & $\begin{array}{l}\text { Lymphocyte } \\
\%\end{array}$ & $80.85 \pm 1.75^{*}$ & $62.75 \pm 0.35$ & $57.45 \pm 2.75$ & $58.05 \pm 1.45$ & $63.6 \pm 0.4$ \\
\hline & $\begin{array}{l}\text { T RBC } \\
x 10^{6} / \mu \mathrm{l}\end{array}$ & $5.81 \pm 0.06$ & $5.35 \pm 0.27$ & $6.09 \pm 0.19$ & $5.99 \pm 0.01$ & $6.15 \pm 0.17$ \\
\hline & $\begin{array}{l}\text { Hemoglobin } \\
\text { g/dl }\end{array}$ & $12.25 \pm 0.45$ & $12.0 \pm 0.5$ & $11.85 \pm 0.15$ & $11.95 \pm 0.05$ & $12.15 \pm 0.35$ \\
\hline \multirow[t]{11}{*}{14} & $\begin{array}{l}\text { Joint fluid } \\
\text { culture }\end{array}$ & ++++ & ---- & $-\cdots$ & $-\cdots$ & $-\cdots$ \\
\hline & $\begin{array}{l}\text { Heart } \\
\text { rate/min }\end{array}$ & $121 \pm 1.0$ & $126 \pm 1.0$ & $119 \pm 1.0$ & $120 \pm 0.0$ & $125.5 \pm 5.5$ \\
\hline & $\begin{array}{l}\text { Respiratory } \\
\text { rate }\end{array}$ & $110.5 \pm 0.5$ & $114 \pm 1.0$ & $111 \pm 1.0$ & $111.5 \pm 1.5$ & $117 \pm 2.0$ \\
\hline & $\begin{array}{l}\text { Body temp. } \\
{ }^{\circ} \mathrm{C}\end{array}$ & $39.1 \pm 0.0$ & $39.0 \pm 0.0$ & $39.0 \pm 0.0$ & $39.0 \pm 0.0$ & $39.0 \pm 0.0$ \\
\hline & $\begin{array}{l}\text { Joint } \\
\text { diameter } \\
\text { /cm }\end{array}$ & $1.75 \pm 0.05^{*}$ & $1.2 \pm 0.1$ & $1.15 \pm 0.05$ & $1.25 \pm 0.05$ & $1.3 \pm 0.0$ \\
\hline & $\begin{array}{l}\text { ESR m.m } \\
\text { /hr. }\end{array}$ & $4.1 \pm 0.1 *$ & $1.5 \pm 0.5$ & $2.0 \pm 0.0$ & $1.5 \pm 0.5$ & $2.0 \pm 0.0$ \\
\hline & RF & +++- & $\ldots$ & $\ldots$ & $\ldots$ & $\ldots$ \\
\hline & $\begin{array}{l}\text { T } \quad \text { WBC } \\
\times 10^{3} / \mu \mathrm{l}\end{array}$ & $12.5 \pm 0.15^{*}$ & $8.05 \pm 0.05$ & $8.25 \pm 0.05 *$ & $8.60 \pm 0.1$ & $8.0 \pm 0.1$ \\
\hline & $\begin{array}{l}\text { Lymphocyte } \\
\%\end{array}$ & $87.0 \pm 1.0 *$ & $62.75 \pm 0.35$ & $57.45 \pm 2.7$ & $58.0 \pm 1.4$ & $63.6 \pm 4.0$ \\
\hline & $\begin{array}{l}\text { T RBC } \\
\times 10^{6} / \mu 1\end{array}$ & $5.16 \pm 0.16$ & $5.53 \pm 0.27$ & $6.09 \pm 0.19$ & $5.99 \pm 0.01$ & $6.15 \pm 0.17$ \\
\hline & $\begin{array}{l}\text { Hemoglobin } \\
\mathrm{g} / \mathrm{dl}\end{array}$ & $11.9 \pm 0.1$ & $12.0 \pm 0.5$ & $11.85 \pm 0.15$ & $11.95 \pm 0.05$ & $12.15 \pm 0.3$ \\
\hline
\end{tabular}


day $0:$ is refer to the experimental animals has no infected (pre challenge), and the other parameters of other days were compared with those.

$(*)$ there are a significant variation at $\mathrm{p}<0.05$ between values.

(-) this sign is referring to negative test result. And (- - -) indicate four animal in group.

(+) this sign is referring to positive test result. And (++++) indicate four animal in group. 


\begin{tabular}{|c|c|c|c|c|c|c|}
\hline \multirow{2}{*}{$\begin{array}{l}\text { Days after } \\
\text { treatment }\end{array}$} & \multirow[t]{2}{*}{ Parameters } & \multicolumn{5}{|c|}{ Infected animals groups \& AGE doses } \\
\hline & & $\begin{array}{l}\text { A } \\
50 \mathrm{mg} / \mathrm{kg} \\
\text { B.W } \\
\end{array}$ & $\begin{array}{l}\text { B } \\
70 \mathrm{mg} / \mathrm{kg} \\
\text { B.W }\end{array}$ & $\begin{array}{l}\text { C } \\
100 \mathrm{mg} / \mathrm{kg} \\
\text { B.W }\end{array}$ & $\begin{array}{l}\text { D } \\
110 \mathrm{mg} / \mathrm{kg} \\
\text { B.W }\end{array}$ & $\begin{array}{r}\mathrm{E} \\
\text { control }\end{array}$ \\
\hline \multirow[t]{11}{*}{0} & Heart rate $/ \mathrm{min}$ & $128.5 \pm 1.5$ & $124 \pm 1.0$ & $123 \pm 1.0$ & $126.5 \pm 1.5$ & $137 \pm 2.0$ \\
\hline & Respiratory rate & $117.5 \pm 2.5$ & $117 \pm 1.0$ & $119.5 \pm 0.5$ & $117.5 \pm 4.5$ & $127 \pm 1.0$ \\
\hline & Body temp. ${ }^{\circ} \mathrm{C}$ & $39.3 \pm 0.0$ & $39.1 \pm 0.05$ & $39.2 \pm 1.0$ & $39.3 \pm 0.1$ & $39.5 \pm 0.0$ \\
\hline & Joint diameter /cm & $1.75 \pm 0.05$ & $1.45 \pm 0.15$ & $1.35 \pm 0.05$ & $1.55 \pm 0.15$ & $1.7 \pm 0.1$ \\
\hline & Joint fluid culture & +++ & +++ & +++ & +++ & +++ \\
\hline & ESR m.m /hr. & $3.5 \pm 0.5$ & $4.0 \pm 0.0$ & $4.0 \pm 1.0$ & $2.5 \pm 1.5$ & $4.5 \pm 0.5$ \\
\hline & RF & ++- & +++ & +++ & +++ & ++ \\
\hline & $\mathrm{T} \mathrm{WBC} \times 10^{3} / \mu \mathrm{l}$ & $12.9 \pm 0.1$ & $14.2 \pm 0.3$ & $13.85 \pm 1.1$ & $14.6 \pm 0.4$ & $13.95 \pm 0$ \\
\hline & Lymphocyte \% & $81.5 \pm 2.5$ & $89.5 \pm 1.5$ & $76.0 \pm 16.0$ & $87.35 \pm 1.65$ & $82.0 \pm 7.0$ \\
\hline & $\mathrm{T} \mathrm{RBC} \times 10^{6} / \mu \mathrm{l}$ & $4.9 \pm 0.4$ & $5.45 \pm 0.05$ & $5.15 \pm 1.0$ & $5.05 \pm 0.25$ & $5.45 \pm 0.5$ \\
\hline & Hemoglobin g/dl & $12.0 \pm 1.0$ & $11.7 \pm 0.6$ & $12.5 \pm 1.5$ & $12.35 \pm 0.85$ & $12.85 \pm 1$ \\
\hline \multirow[t]{4}{*}{1} & Heart rate $/ \mathrm{min}$ & $129.5 \pm 0.5$ & $122 \pm 1.0$ & $121 \pm 1.0$ & $122.5 \pm 0.5$ & $139 \pm 1.0$ \\
\hline & Respiratory rate & $120.5 \pm 1.5$ & $115 \pm 1.0$ & $113 \pm 2.0$ & $114 \pm 1.0$ & $127 \pm 1.0$ \\
\hline & Body temp. ${ }^{\circ} \mathrm{C}$ & $39.3 \pm 0.0$ & $39.05 \pm 0.05$ & $39.1 \pm 0.0$ & $39.1 \pm 0.05$ & $39.6 \pm 0.1$ \\
\hline & Joint diameter $/ \mathrm{cm}$ & $1.75 \pm 0.05$ & $1.45 \pm 0.15$ & $1.35 \pm 0.05$ & $1.55 \pm 0.15$ & $1.7 \pm 0.1$ \\
\hline \multirow[t]{5}{*}{4} & Joint fluid culture & +++ & -++ & --- & --- & ++ \\
\hline & Heart rate /min & $129.5 \pm 0.5$ & $124 \pm 1.0$ & $121 \pm 1.0$ & $122.5 \pm 0.5$ & $139 \pm 1.0$ \\
\hline & Respiratory rate & $119.5 \pm 0.5$ & $117.5 \pm 2.5$ & $113 \pm 2.0$ & $114 \pm 1.0$ & $127 \pm 1.0$ \\
\hline & Body temp. ${ }^{\circ} \mathrm{C}$ & $39.1 \pm 0.0$ & $39.05 \pm 0.05$ & $39.05 \pm 0.05 *$ & $39.0 \pm 0.0 *$ & $39.6 \pm 0.1$ \\
\hline & Joint diameter /cm & $1.75 \pm 0.05$ & $1.45 \pm 0.1$ & $1.25 \pm 0.05^{*}$ & $1.35 \pm 0.1$ & $1.7 \pm 0.1$ \\
\hline \multirow[t]{11}{*}{14} & Joint fluid culture & -++ & --+ & - - & --- & ++ \\
\hline & Heart rate/min & $122.5 \pm 0.5$ & $122.5 \pm 0.5$ & $122.5 \pm 0.5$ & $122.5 \pm 0.5$ & $129.5 \pm 0$ \\
\hline & Respiratory rate & $114 \pm 1.0$ & $114 \pm 1.0$ & $114 \pm 1.0$ & $114 \pm 1.0$ & $119.5 \pm 0$ \\
\hline & Body temp. ${ }^{\circ} \mathrm{C}$ & $39.1 \pm 0.0$ & $39.0 \pm 0.0$ & $39.0 \pm 0.0 *$ & $39.0 \pm 0.0^{*}$ & $39.1 \pm 0.0$ \\
\hline & Joint diameter /cm & $1.4 \pm 0.0$ & $1.25 \pm 0.05$ & $1.15 \pm 0.05^{*}$ & $1.25 \pm 0.0 *$ & $1.95 \pm 0.0$ \\
\hline & ESR m.m /hr. & $3.5 \pm 0.5$ & $3.5 \pm 1.0$ & $2.5 \pm 0.5^{*}$ & $2.5 \pm 0.5$ & $5.0 \pm 0.0$ \\
\hline & $\mathrm{RF}$ & ++- & -++ & +-- & +-- & ++ \\
\hline & $\mathrm{T} \mathrm{WBC} \times 10^{3} / \mu \mathrm{l}$ & $10.9 \pm 0.9$ & $13.85 \pm 1.15$ & $10.85 \pm 0.75 *$ & $10.3 \pm 0.80 *$ & $13.7 \pm 0.8$ \\
\hline & Lymphocyte \% & $80.0 \pm 2.0$ & $76.0 \pm 1.6$ & $72.0 \pm 0.5^{*}$ & $70.1 \pm 1.9 *$ & $84.5 \pm 0.4$ \\
\hline & $\mathrm{T} \mathrm{RBC} \times 10^{6} / \mu \mathrm{l}$ & $6.1 \pm 0.35^{*}$ & $5.45 \pm 0.05$ & $5.80 \pm 0.9$ & $3.25 \pm 0.25^{*}$ & $5.45 \pm 0.5$ \\
\hline & Hemoglobin g/dl & $12.5 \pm 0.6$ & $12.0 \pm 0.3$ & $12.5 \pm 1.5$ & $8.65 \pm 0.45^{*}$ & $12.8 \pm 1.2$ \\
\hline
\end{tabular}

day $0:$ refer to the experimental animals had infected with arthritis(pretreatment). and the other parameters of other days were compared with those.

(*) there are a significant variation at $\mathrm{p}<0.05$ between values.

(-) this sign is referring to negative test result. And (- - -) indicate three animal in group.

$(+)$ this sign is referring to positive test result. And $(+++)$ indicate three animal in group. 